there is also a distinction between part of the procoss of 'making' myths, and mythologies, which the author seems scarcely aware of. From such beginnings, without any analysis of the mechanisms of inheritance, mythologies are classified into those of the hunter, the planter, the ancient city dweller, and the peoples of prehistory; and an attempt is made to show, using the theories of tho diffusionist and Kulturkreis schools-unconvincingly, I think-how such types of myths might have spread or diffused. The classification is useful : there are somo interesting passages on the cuckoo, divine kings, the ritual love-death, shamanism, cave painting, a stickleback, and palæolithic and neolithic man, but the relations botween the inherited imago-imprinted on man's mind some 600,000 years ago, the poetic vision, cultural determinism, and culture change and diffusion remain -as one would expect-wholly obscure.

Diffusionist theory is necessary to this kind of construct, and some theories might provide models for what to-day is callod 'acculturation'. Why cite Forbenius and Haeckel-who failed to construct such a model-and not Perry and Elliot Smith-who did ? The seminal work of Hocart, Halbwachs, Van Gennop, Levi-Strauss, and Leenhardt is not mentioned. Indeed, these authors can offer little to one who, though some sort of Jungian, is determined to take his departure from Bastian without taking Neumann into account.

If there were a personal and imaginativo synthesis the strange choice of authorities would not matter. For the central problems-how myths come to exist, penetration of the divine or mystical experience, the relation of myths to particular kinds of social structure and culture-are real and outstanding. But they will not yield to grandiose pretensions, second-hand psychology, muddled sociology, bad history, and an appalling confusion of biological and cultural levels.

K. O. L. BURRIDGE

\section{RADIATION AND THE BROAD BEAN}

Radiation Biology of Vicia faba in Relation to the General Problem

By Dr. John Read. Pp. xxii +270. (Oxford: Blackwell Scientific Publications ; Springfield, Ill. : Charles C. Thomas, 1959.) 45s. net.

$7 \mathrm{HE}$ roots of broad bean seedlings are stout and not very exacting in their requirements for good growth. The meristematic and differentiating zones are well demarcated, and squash preparations can easily be made to display the chromosomes in dividing cells of the root-tip. The chromosomes themselves are large and only twelve in number. The growthrate of the roots can easily be measured by their increase in length. These aro the main characteristics which have led many of those working on the effects of radiation on living systems to adopt the broad bean as their experimental material.

Dr. Read givos a systomatic account of this work, restricting himself almost exclusively to investigations published after 1939. The reader is led in the early chapters through the effocts of radiation on growth-rate, to a consideration of the inhibition of mitosis by radiation. It is the contention of the author that many effocts of radiation on growth-rate stem from damage to the genetic material, and it is to an analysis of chromosome aberrations in relation to radiation that much of the book is devoted. The various conflicting theories as to the nature of chromosome aberrations are considered in detail in the light of all the available evidence as to the influence of the type of radiation, the dose-rate and the various environmental factors which affect the production of aberrations. Deoxyxibonucleic acid synthesis after radiation is considered briefly, as is a comparison of radiation with radiomimotic chemicals in thoir effects on the bean root. Throughout, the results obtained with broad beans roots are compared with those obtained from othor living systems. In a final chapter a valuable summary is made of the comparisons of this type which have been made in previous chapters. Dr. Read presents a formidable case for the utility of his superficially trivial experimental material. There is a bibliography of more than two hundred titles.

The presentation of tho book is excellent, the type being large and clear and the text figures bold. Those intimately concerned with the biological effects of radiation will be grateful to Dr. Read for drawing together in such an accessible manner all the important information on Vicia faba and radiation.

\section{HISTORY OF ENGINEERING INVENTION}

Science as History

The Story of Man's Technological Progress from Steam Engine to Satellite. By Heinz Gartmann Translated from the Gorman by Alan G. Readett. Pp. xvii $+348+51$ photographic illustrations. (London: Hodder and Stoughton, Ltd., 1960.) 25s. net.

CCIENCE as History" has a more accurate subtitle "The Story of Man's Tochnological Progress from Steam Engine to Satellite". It is a popular account of engineering invention and development written around a number of the most important examples. The advance of the steam engine, motorcar and aeroplane, is followed by chapters on telecommunications, radio, radar, atomic physics, automation, and space exploration.

The author has not attempted a critical appraisal of the topics chosen--the work is in no way 'learned' ; he has sought sonsibly to recount some history in an interesting manner. In some chapters unnecessary detail clouds the overall pattern; for example, so many names appear in the steam engine section that the really important contributors never emerge. Thero is also a probably unavoidable national bias. When the United States, Britain, Europe and the U.S.S.R. are all working on similar problems, often under conditions of secrecy, it is exceedingly difficult to be just.

Some chapters lack balance; the space devoted to balloons and Zeppelins is twice that devoted to the immensoly fortilo period of aviation history from 1903 to date. Finally, the treatmont of Dr. Eugen Sänger's locture on relativistic mechanics applied to space flight is positively melodramatic.

In spite of those faults the book is immensoly readable, beautifully produced, has a bibliography, and does display an approciativo undorstanding of the important and exciting developments selected. It deserves a wide audience. J. I. Stollery 